\title{
ACOSTĂRI SUPRAREALISTE ÎN ARHITECTURĂ
}

\author{
stud. arh. Laura Săbău Tătar
}

Universitatea de Arhitectură și Urbanism "Ion Mincu"

sabaulaura95@yahoo.com

\section{Rezumat}

Relația dintre arhitectură și suprarealism a surprins aspecte cheie ale lumii înconjurătoare- corpul și casaconturând arhitectura ca element introspectiv. Ambiguitatea noțiunii de spațiu face ca arhitectura să poată trezi de la cele mai adânci temeri, la cele mai frumoase tentații, devenind asfel un joc psihic. Definirea arhitecturii ca unealtă de autocunoaștere prin trezirea unor anumite stări, face ca ea să fie mediul cel mai potrivit de manifestare al suprarealismului.

Pentru suprarealiști, căminul era locul primelor temeri, acestea manifestându-se prin elemente precum scara, ușa, fereastra, dulapul, conturând un spațiu al misterelor întunecate și al relațiilor ambigue dar tensionate între psihic și elemente cu caracter mnemonic. Arhitectura lui Le Corbusier lasă loc de manifestare a suprarealismului prin conturarea unor cadre stranii, în care absența apăsătoare a omului redă o neliniște împăcată. Ea marchează diverse motive specifice curentului de avangardă, cum ar fi motivul ferestrei spre nimicnicia cerului, al mobilei așezate într-un mod straniu, al ambiguității exterior-interior.

Corpul uman a fost puternic reinterpretat de suprarealism. Fiind supus unui continuu proces de metamorfoză în care asimilarea mutațiilor îl transformă într-un element ambiguu aflat între masă și vid, se ajunge la conturarea psihicului uman prin puterea de a reda straniul, tortura și tentația. Arhitecți contemporani precum Daniel Libeskind și Coop Himmelblau reinterpretează în lucrările lor corpul omenesc ca element mutilat, generând o stare de teamă, ca în cazul Muzeului evreiesc din Berlin.

În concluzie, descoperirea elementelor suprarealiste în spațiul real, construit, ajută la o întelegere mai bună a gândirii umane.

Cuvinte cheie: suprarealism, arhitectură, organic, modernism, ambiguitate, corp, straniu, vis 
Suprarealismul a însemnat mai mult decât o mișcare de avangardă în pictură și literatură, a conturat un mod de gândire în care lumea văzută și cea nevăzută, a misterelor și a viselor, se împletesc creând o realitate absolută. Aceasta este definită de dorința omului de cunoaștere dincolo de hotarele lumii raționale, abordând realul și visul ca entități la fel de importante pentru creația artistică, și pentru înțelegerea lumii. Suprarealismul caută anihilarea raportului de contradicție prin puterea minții și a introspecției, ca sursă a revelațiilor. Viziunea suprarealistă este conturată de către André Breton, în scrierile sale: „Totul ne conduce la crezul că există un anumit punct al minții noastre în care viața și moartea, realul și imaginarul, trecutul și viitorul, comunicabilul și incomunicabilul, înaltul și josul încetează a fi contradictorii" (Breton $1969,12)^{1}$. Astfel, arhitectura poate oferi suparealismului o putere mare de manifestare datorită uneltei sale principale de lucru: spațiul, reușind să transforme lumea înconjurătoare într-un joc psihic, al trăirilor interioare.

Spațiul suprarealist se conturează în mod straniu, uneori limitele sale generând forme cu aspect de pântec și în care ambiguitatea și absența joacă un rol esențial în transmiterea unui sentiment apăsător. Motive precum cel al ferestrei spre nimicnicia cerului, al ambiguității exterior-interior, se regăsesc și în arhitectură ca tratări spațiale care emană un sentiment de neliniște. Locuința, în viziunea suprarealiștilor, lasă loc de manifestare a angoaselor, a straniului în ciuda funcțiunii sale primordiale de adăpost. După cum afirmă Anne Troutman:

Nu consider casa ca loc ferit. Pentru mine, este o coliziune între vis, coșmar și circumstanțe, un portret al vieții interioare. Adăpostul primar este de-asemenea locul fricilor primare. Înterioarele sale sunt o hartă a conștientului și a inconștientului: a siguranțelor sale și a nesiguranțelor. În casă domnește pericolul. Dulapurile, holurile, scările, ușile și ferestrele, podurile, subsolurile, streșinile, vitrinele se extind si se contractă cu teamă și dorință. Ele sunt partea întunecată a casei, în care identitatea și siguranța vieții domestice este înlocuită, condensată, fragmentată. (Troutman 1997, 143)²

\section{Locuința organică}

Ideea interpretării spațiului intrauterin în arhitectură s-a născut o dată cu mișcarea Dadaistă. Tristan Tzara, în lucrarea „D 'un certain automatisme du Gout” vorbește despre reîntoarcerea la formele organice, neregulate ale casei, regăsite în memoria adăposturilor primitive, în conformitate $\mathrm{Cu}$ „viziunea asupra vieții intrauterine care nu știe nimic despre acea estetică a castrării numită modernă" (Tzara 1933, 847)33. În acest spirit, se definesc noi încercări de exploatare a spațiului domestic, în care limitele dintre exterior și interior, natural și sintetic se estompează.

Între anii 1924 și 1950, Frederick Kiesler concepe proiectul denumit „Endless House” (Fig. 1) în care locuirea se desfășoară într-un spațiu definit de linii curbe, dinamic, lumina jucând un rol primordial. Coaja clădirii pare că se descompune, lâsând loc luminii să pătrundă până în străfundurile camerei, fără ca aceasta să fie obturată de geometria rigidă specifică locuințelor obișnuite. Impresia de infinit este dată de traseul interior care nu pare a avea un punct

\footnotetext{
1 trad. ns. „Tout porte à croire qu'il existe un certain point de l'esprit d'où la vie et la mort, le réel et l'imaginaire, le passé et le futur, le communicable et l'incommunicable, le haut et le bas cessent d'être perçus contradictoirement."

2 trad. ns.

${ }^{3}$ trad. ns., „dans sa vision de vie intra-utérine qui, elle, ne connaît pas l'esthétique de castration dite moderne”
} 
terminal, marcându-se astfel intenția de conturare a unui mediu specific visului, în care libertatea fizică și confortul să conlucreze cu libertatea psihică. (Fig. 2)

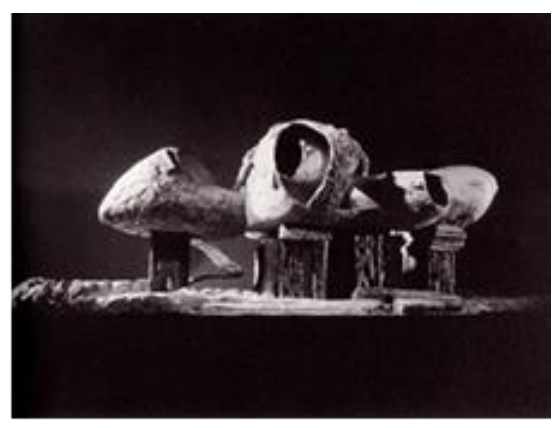

Fig. 1. F. Kiesler, Endless House (www.archdaily.com)

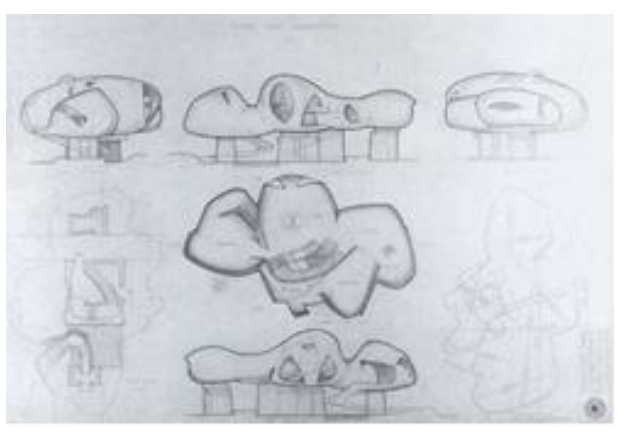

Fig. 2. F. Kiesler, Endless House (www.archdaily.com)

O abordare contemporană a conceptului suprarealist de casă-pântec este redată de proiectul RV Prototype House al arhitectului american Greg Lynn, în care interiorul este învelit într-o coajă cu aspect de ou din fibră de carbon, explorându-se minimalizarea spațiului necesar locuirii și obținerea unei amprente la sol cât mai mici. Senzația de straniu este accentuată prin conturarea unui spațiu în care podeaua poate deveni tavan și invers, la fel ca în cazul proiectului Endless House, doar că aici libertatea de mișcare este mai puternică datorită unui mecanism aflat la baza construcției care o poate roti în orice direcție. Astfel, funcțiunile și mobila sunt marcate pe tot conturul coajei, liniile curbe facilitând flexibilitatea spațială. (Fig. 3)
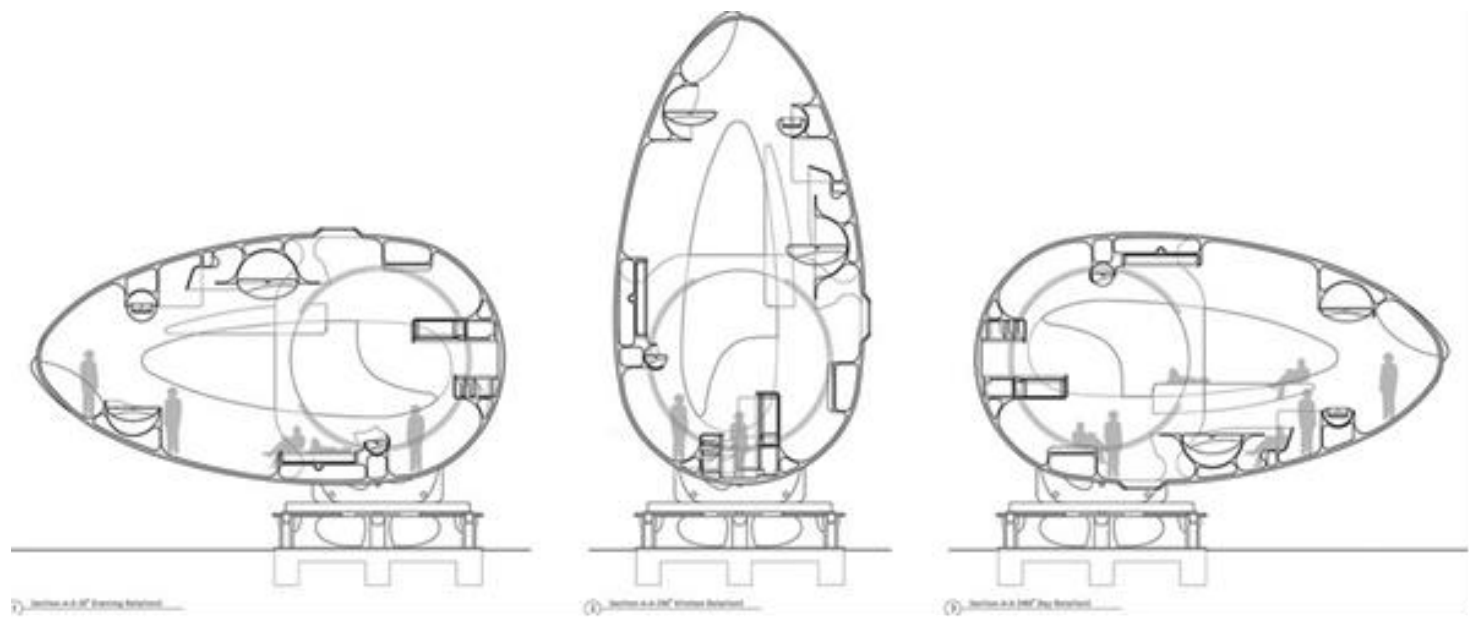

Fig. 3. G. Lynn, RV Prototype House (www.archdaily.com)

\section{Suprarealism și Modernism}

Arhitectura modernă a căutat atingerea raționalului absolut prin intermediul formelor regulate, albe, conturând un spațiu cu funcțiune clară. Însă, dialogul neobișnuit dintre rațional și suprarealism este conturat în atmosfera stranie, sinistră uneori a arhitecturii moderne adusă 
la apogeul său în clădirile lui Le Corbusier. Ambiguitatea exterior-interior, senzația apăsătoare a absenței și singurătatea sunt doar câteva motive redate în pictura suprarealistă și regăsite în arhitectura sa. Ambiguitatea spațială se conturează în clădirile sale prin încorporarea naturii ca element definitoriu al locuirii. Natura este percepută ca o extensie a camerei interioare, făcând ca spațiul-adăpost al locuinței și cel al necunoscutului să se întrepătrundă.

Elementul natural încadrat în ramă, regăsit în arhitectură, este specific picturii suprarealiste și des utilizat de arhitectul modernist în proiectele sale. În cazul clădirii Pavillon de I’ Esprit (Fig. 4), suprimarea peretelui pe dublă înălțime al terasei face ca natura să invadeze spațiul, încadrând-o în același timp ca într-un tablou. Mobila delicată - măsuța de ceai, cu scauneleconturează sentimentul apăsător al absenței omului dar și dimensiunile stranii ale spațiului. Alexander Gorlin, în lucrarea „Fantoma din Mașinărie” aseamnănă spațiul din ", camera exterioara supradimensionată” care pare a fi într-un context ireal, cu cel al tabloului „Copilăria lui Icar", realizat de pictorul René Magritte în anul 1960: "În acestă cameră gargantuească ce se deschide înspre pădure" (Gorlin 2005, 106) ${ }^{4}$, se află un tablou care înfățișează cerul, rezemat de unul cu ferestre și în care jockey-ului galopând înspre exterior apare minuscul. Asemănările, astfel, se evidențiază prin prezența ramei care încadrează exteriorul și prin relația dimensionala dintre obiect și spațiu. (Fig. 5)

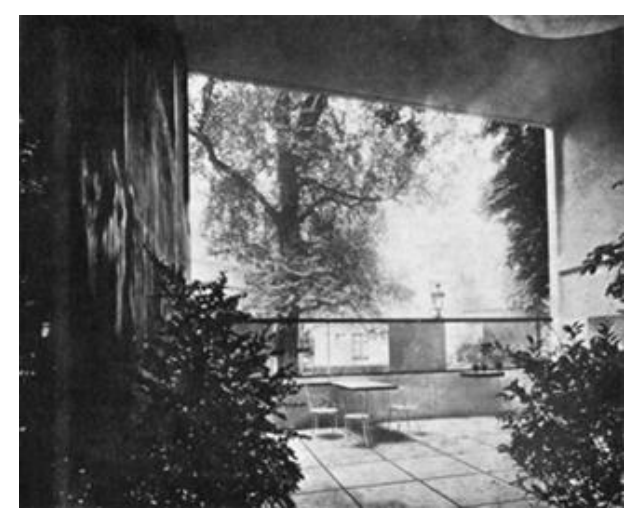

Fig. 4. Le Corbusier, Pavillon de I’ Esprit (T. Mical, Surrealism and Architecture)

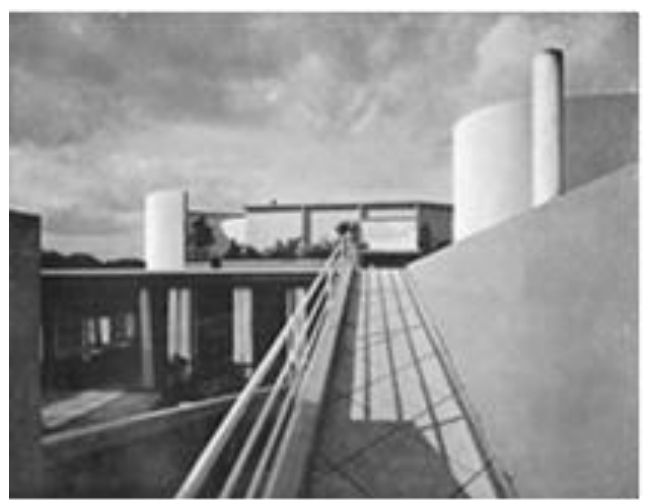

Fig. 6. Le Corbusier, Villa Savoye (T. Mical, Surrealism and Architecture)

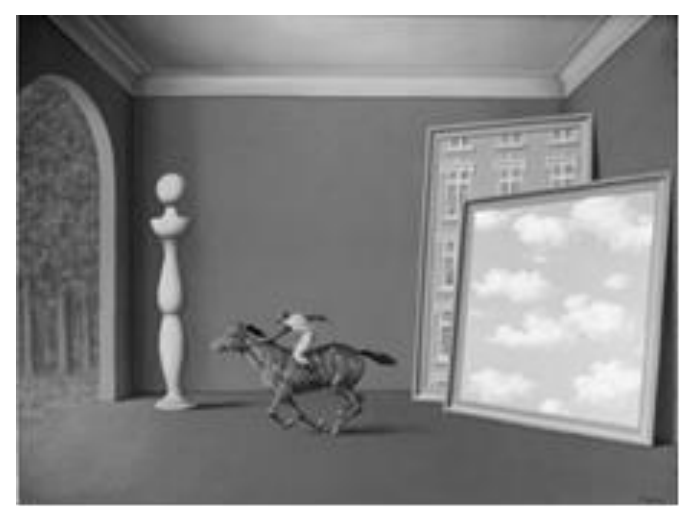

Fig. 5. René Magritte, Copilăria lui Icar (T. Mical, Surrealism and Architecture)

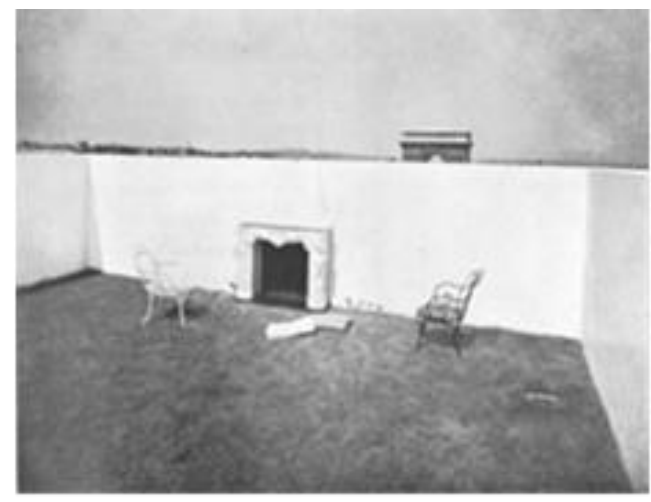

Fig. 7. Le Corbusier, Ap. Beistegui (T. Mical, Surrealism and Architecture)

${ }^{4}$ trad. ns. 
Motivul ramei este prezent și la Villa Savoye, de data aceasta elementul conturat fiind cerul. Clădirea este închisă pe cele patru laturi, interiorul luminându-se prin ferestre în bandă, înguste, producând un efect ascendent. Construcția pare o întregă cameră exterioară deschisă înspre cer, efect accentuat de gestul straniu de conturarea a unei camere pe acoperiș care se descompune înspre exterior prin suprimarea pereților și tavanului. (Fig. 6)

Apartamentul Beistegui poartă cea mai puternica amprentă suprarealistă dintre operele lui Le Corbusier. Acoperișul grădină este tratat precum o cameră exterioară de unde a fost suprimat tavanul și unde pereții acționează ca un scut împotriva haosului urban, încadrând astfel, ca întro ramă, cerul. Prezența stranie a șemineului și a mobilierului firav, așezate pe podeaua înierbată, dau o senzație ciudată. (Fig. 7)

Spiritul suprarealist descris în arhitectura lui Le Corbusier își găsește apogeul în arhitectura Casei Cordoba, proiectată de Emilio Ambasz în anul 1975, în Sevilla (Fig. 8). Peisajul andalusian contribuie la întregirea cubului marcat de cei doi pereți supli, albi, împreună generând o imagine cu tentă suprarealistă. Locuirea are loc sub pământ, într-un spațiu delimitat de forme curbe, ce evocă conceptul casei- pântec. Se obține astfel un sentiment de siguranță și intimitate care este însă în contrast cu senzația generată de arhitectura exteriorului. Curtea interioară conturează motivul suprarealist al ramei către cer, pe când cei doi pereți înalți contribuie la trecerea graduală de la siguranță la necunoscut, de la spațiul subteran la cel suprateran. Această trecere este marcată de scara care urcă înspre punctul de observație, scară ce simbolizează drumul cunoașterii, presărat cu teamă. Astfel, arhitectura creează un dialog între spațiul exterior, siguranță și teamă, reușind să le întrepătrundă. (Fig. 9)

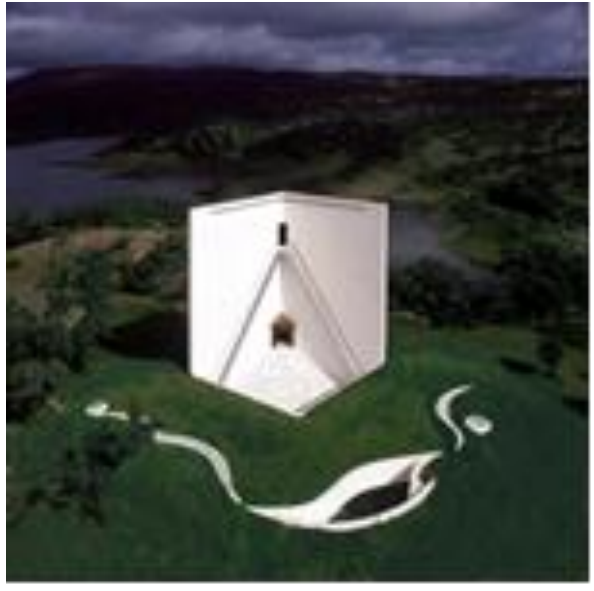

Fig. 8. E. Ambasz, Cordoba House (www.archdaily.com)

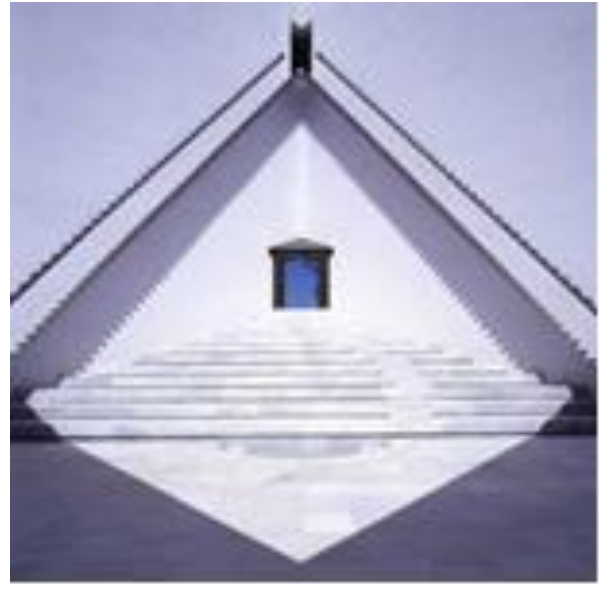

Fig. 9. E. Ambasz, Cordoba House (www.archdaily.com)

În exemplele prezentate, legătura dintre arhitectură și suprarealism îmbogățește experiența spațială și naște senzații care duc spre un joc psihic între teamă, mister și confort.

Nuanțele suprarealiste nu se limitează doar la nivelul programului de locuire, arhitecții contemporani căutând inspirația în acest curent pentru multe alte programe de arhitectură. 


\section{Corpul uman ca sursă de generare a spațiului}

Suprarealismul a avut ca obiect primordial de lucru corpul. Supus unui continuu proces de metamorfoză, el asimilează diverse mutații, de la geometrii ciudate, la mașinărie și elemente din natură, devenind un element ambiguu, aflat mereu la limita dintre material și imaterial. Prin mutilarea corpului, suprarealismul a creat o oglindă a terorii umane. De exemplu, în 1936, Salvador Dalí pictează „,Construcție moale cu fasole fiartă (Premoniție a războiului Civil)”, în care torsiunea corpului uman sugerează ororile produse de război, în care omul se distruge pe el insuși. Scena macabră este accentuată de boabele de fasole fiartă care, prin memoria olfactivă, aduc aminte de moarte. (Fig. 10)

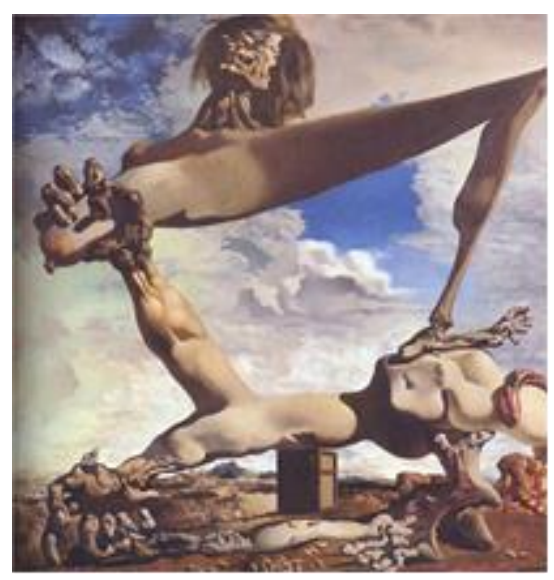

Fig. 10. S. Dali, Construcție moale cu fasole fiartă (Premoniție a războiului Civil)

Pentru Anthony Vidler, arhitecți precum Daniel Libeskind și Coop Himmelb(I)au fundamentează în lucrările lor conceptul înscripției corpului uman în arhitectură. Acesta însă, este perceput ca o metaforă conturată prin fragmentare dusă până la extrem- formând „un „corp" radical diferit față de cel aflat în centrul tradiției umaniste” (Vidler 1996, 69)5. Astfel „acest corp nu mai are rolul de a centra, de a repara sau de a stabiliza. Mai degrabă, limitele sale, interioare sau exterioare, par complet ambigue și extensive; formele sale, precise sau metaforice nu mai sunt limitate la figura umană reconoscibilă ci îmbrățișează toată existența de la embrionar la monstruos" (Vidler 1996, 70).

Muzeul Evreiesc din Berlin, proiectat de Daniel Libeskind în 1999 are la baza conceptului fragmentarea corpului uman până la absență. „Corpul” este perceput ca o metaforă a durerii și este simțit la nivelul spațiilor vide, a ferestrelor care par niște zgârieturi și a gesturilor arhitecturale dure. (Fig. 11 şi Fig. 12)

O altă modalitate de exploatare a corpului ca unealtă a cunoașterii și a creației esteabordată de biroul Coop Himmelb(I)au. În cadrul lucrării „The Tower of Babel Revisited”, arhitecții abordează corpul ca instrument de măsurare a raportului dintre om și elementele care definesc spațiul urban: "Ochii noștri devin turnuri, frunțile noastre poduri, fețele peisaje, și

\footnotetext{
${ }^{5}$ trad. ns.

${ }^{6}$ trad. ns.
} 
corpul nostru plan" (Coop Himmelb(I)au 1993, 29)7. Acestă abordare duce la fragmentarea corpului până la limita în care acesta devine irecognoscibil, elemente componente asimilând dimensiuni monstruoase. În acest fel, se explorează relația dimensională dintre om și oraș, raportul dintre scara umană și cea a mediului urban în care locuim. Acestă explorare este dusă mai departe prin încercările de modelare a feței umane într-o formă arhitecturală, prin mutilare, Coop Himmelb(I)au tratând-o ca pe o "fațadă a emoțiilor" (Coop Himmelb(I)au 1991, $21)^{8}$. Astfel, construcția și distrucția nu mai pot fi percepute ca antonime ci ca elemente ce conlucrează spre desăvârșirea actului creator, atât la nivelul de concept cât și la cel formal. Arhitectura asimilează forme zbuciumate care redau o senzație de neliniște, sentiment pe care Coop Himmelb(I)au îl exploatează ca o componentă fundamentală a experienței spațiale.

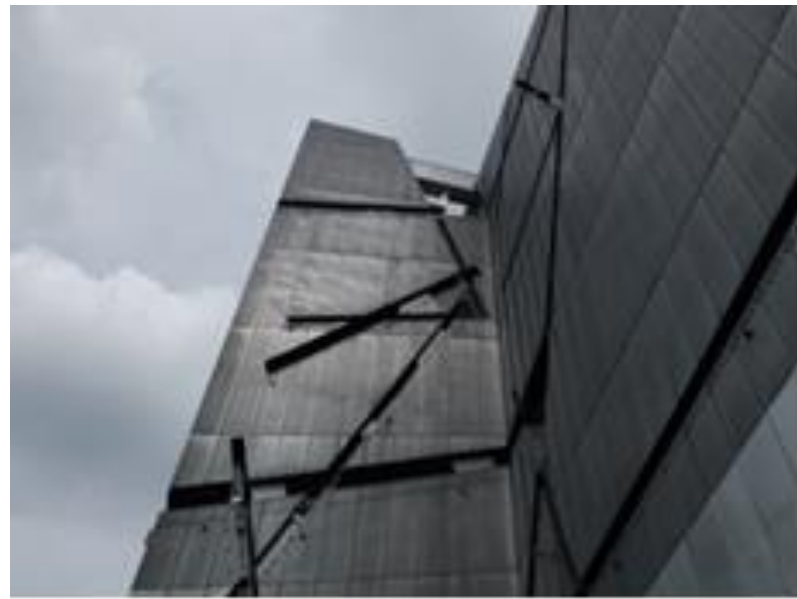

Fig. 11. D. Libeskind, Jewish Museum

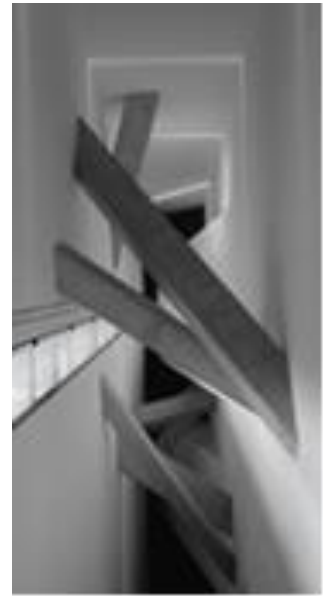

Fig. 12. D. Libeskind, Jewish Museum

Clădirea care găzduiește Muzeului de Artă Contemporană și Expoziția de Planificare (MoCAPE) din orașul Shenzhen, este caracterizată prin ambiguitatea interior-exterior redată de transparența fațadei care oferă o vedere asupra orașului, senzația creată fiind aceea a unui spațiu exterior acoperit. Exemplu de față, explorează arhitectura viscerală prin amplasarea unei „inimi” care are rolul de a genera o legătură între spațiile de expunere ale celor doua muzee, unindu-le astfel sub aceeași coajă. (Fig. 13 şi Fig. 14)

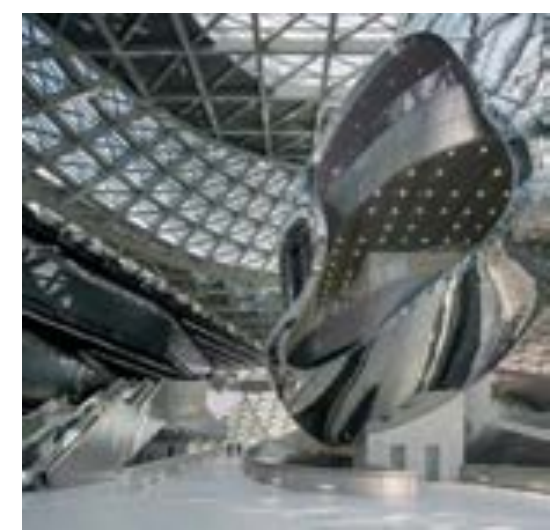

Fig. 13. C. Himmelb(I)au, MoCAPE (www.archdaily.com)

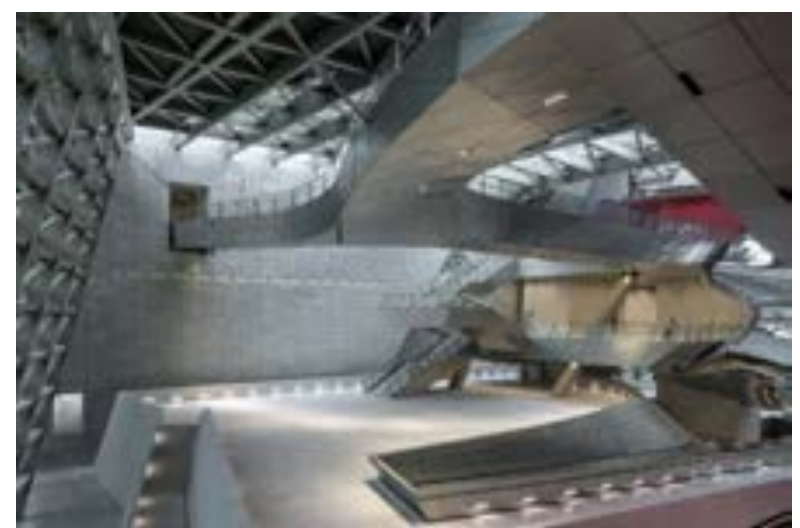

Fig. 14. C. Himmelb(I)au, MoCAPE (www.archdaily.com)

7 trad. ns.

8 trad. ns. 
În concluzie, descoperirea elementelor suprarealiste în spațiul real, construit, ajută la o întelegere mai bună a gândirii umane care tinde să creeze conexiuni între elemente contradictorii, de multe ori în mod inconștient. „Mașinăria de locuit” a lui Le Corbusier, ca apogeu al raționalității, ajunge să portretizeze relații ambigue, stranii între elemente opuse: cer și pământ, interior- exterior, locuire și absență. De asemenea, suprarealismul s-a dovedit a fi o sursă de inspirație pentru arhitecți, exploatând noi mijloace de generare a spațiului și de transmitere a emoțiilor.

Îmbrățișarea formelor onirice ca parte componentă a experienței umane, face ca aceasta să se extindă peste hotarele raționalului care de multe ori ne lasă reci în fața unor posibilități ascunse, intrinseci. Sensibilitatea pe care fiecare dintre noi o poartă are puterea de a modela mediul într-o infinitate de realități personale. Arhitectura, prin unealta sa esențială- spațiul, dă naștere trăirilor interioare, fâcând ca pentru fiecare individ, experiența să fie unică. Spațiul suprarealismului este cuprins de senzualitate prin capacitatea sa de a vibra toate simțurile, făcând ca acesta să fie în continuă mișcare și transformare în timp, în funcție de stările lumiilor interioare ale fiecăruia.

Lucrarea de față a avut ca scop introducerea cititorului în caracteristice spațiale promovate de curentul suprarealist, pentru a-i trezi o anumită curiozitate de exploatare a propriilor sentimente în relație cu mediul înconjurător- cu materia și abstractul.

\section{Referinţe}

Breton, André. (1969). „Manifestoes of Surrealism”, Richard Seaver și Helen R. Lane (trad.). Ann Arbor: The University of Michigan Press (ed)

Coop, Himmelb(I)au. (1991). „On the edge” în Architecture in Transition: Between Deconstruction and New Modernism, Peter Noever ( Munich:Prestel) (ed.)

Coop Himmelb(I)au. (1993). The Tower of Babel Revisited, ANY No. 0 (May/June)

Gorlin, Alexander. (2005). "The Ghost in the Machine” în Thomas Mical, Surrealism and Architecture, Routledge (ed.). Taylor \& Francis Group

Mical, Thomas. (2005). Surrealism and Architecture. Routledge (ed.), Taylor \& Francis Group

Troutman, Anne. (1997). „Inside fear: Secret places and Hidden Spaces in Dwelling”. Nan Ellin (ed.), Architecture and Fear, New York

Tzara, Tristan. (1933). „D`un certain automatisme du Gout”, Minotaure, 3-4, Decembrie

Vidler, Anthony. (1996). The Architectural Uncanny Essays in the Modern Unhomely. The MIT Press (ed.)

\section{Webografie}

Archdaily http://www.archdaily.com

Dezeen http://www.dezeen.com/ 


\title{
SURREAL MOORING IN ARCHITECTURE
}

\author{
arch. stud. Laura Săbău Tătar \\ „Ion Mincu” University of Architecture and Urbanism \\ sabaulaura95@yahoo.com
}

\begin{abstract}
The relationship between architecture and Surrealism has depicted fundamental aspects of the surrounding world - the body and the house - outlining architecture as an introspective element. The ambiguous notion of space gives architecture the power to awaken feelings from the deepest fears to the most powerful temptations, thus becoming a psychic game. Defining architecture as a tool of self-knowledge by awakening certain feelings, gives the surreal a great power of manifestation.

In the perspective of the Surrealists, the home was the place of the primal fears, that are represented by elements such as: stairs, doors, windows or cabinets, depicting a place of mystery and ambiguous but tense relations between the psychic and mnemonic elements.

Le Corbusier's architecture expresses surreal elements by framing the uncanny, in which the heavy absence of man depicts a peaceful uneasiness. It marks various motifs specific to the avant-garde current, such as the motif of the window to the nothingness of the sky, the furniture placed strangely, the ambiguity of the exterior-interior. The human body was strongly reinterpreted by Surrealism. Subjected to a continuous process of metamorphosis, in which the assimilation of mutations transforms the body into an ambiguous element between mass and vacuum, it defines the human psyche through the power of depicting the uncanny, torture and temptation. Contemporary architects such as Daniel Libeskind and Coop Himmelblau reinterpreted in their works the human body, as a mutilated element, generating a state of fear, as in the case of the Berlin Jewish Museum.

In conclusion, the discovery of surrealistic elements in the real world leads to a better understanding of the human mind.
\end{abstract}

Keywords: surrealism, architecture, organic, Modernism, ambiguity, body, uncanny, unreal 
Surreal meant more than an avangarde movement in painting and literature, it shaped a way of thinking in which the seen and the unseen world of mysteries and dreams combine, resulting in an absolute reality. This is defined as the human's wish to know beyond the rational world borders, aproaching reality and dream as entities as being important for the artistic work and for understanding the world. Surreal tends to annihilate the contradiction report through the power of mind and introspection, as a revelation source. The surreal vision is formed by André Breton, in his writings: "Everything leads us to believe there is a certain point of our mind in which life and death, reality and imagination, past and future, the communicable and the incommunicable, high and low stop being contradictory." Thus, architecture may offer the surreal a greater power of manifestation owing to its main instrument: space, transforming the world in a mental game of inner feelings.

The surreal space strangely shapes, sometimes its limits producing belly shapes in which ambiguity and absence have an essential attribution in sending an overwhelming feeling. Motifs like that of the window toward the nothingness of the sky, of the exterior-interior ambiguity can be found in architecture like spatial treatments emitting a restlessness feeling. In the perspective of the surrealists, the housing allows the manifestation of sadness and strangeness despit of its primary function of shelter. As Anne Troutman states:

I do not believe the house is a safe place. For me, it is a collision of dream, nightmare and circumstance, a portrait of an inner life. The primal shelter is also the site of primal fears. Its interiors are a map of the conscious and the unconscious: of their securities and insecurities. There is danger in the house. Closets, hallways, stairways, doors and windows, attics, basements, eaves and cabinets expand and contract with fear and desire. They are the night side of the house, in which the identity and security of domestic life is displaced, condensed, fragmented. (Troutman 1997, 143)

\section{Organic Housing}

Idea of interpreting the intrauterine space in architecture appeared with Dada movement. Tristan Tzara in the "D 'un certain automatisme du Gout" work mentions about the return to the organic and irregular shapes of the house, found in the memory of primitive shelters, in conformity to "the vision on intrauterine life that doesn't know anything about that esthetics of castration called modern" (Tzara 1933, 847). On this line, new tests of the domestic space exploitation are defined in which the limits between exterior and interior, natural and synthetic fade.

Between the years 1924-1950, Frederick Kiesler has conceived the "Endless House" (Fig. 1) project in which dwelling is in a dynamic space defined by curve lines, the light having a primary attribution. The building shell seems to displace, letting the light to enter the room entrails, without being obturated by the rigid geometry characteristic to the common housing. The impression of infinite is provided by the interior route that doesn't seem to have a terminal point, thus marking the intention of shapping the dream environment in which physical freedom and comfort cooperate with mental freedom. (Fig. 2) 


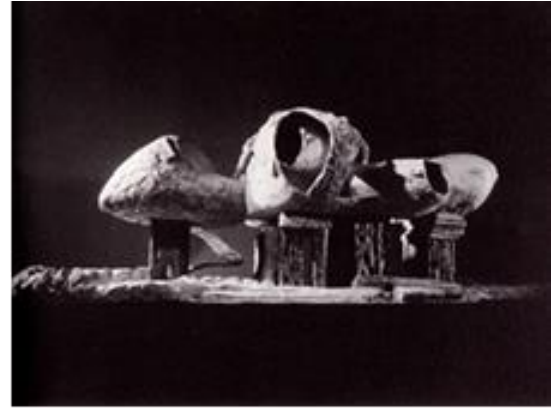

Fig. 1. F. Kiesler, Endless House (www.archdaily.com)

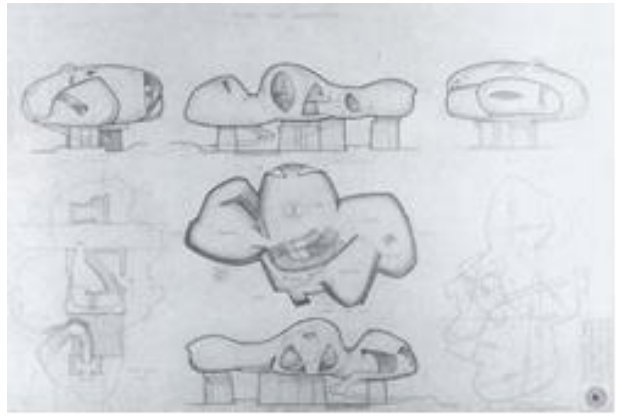

Fig. 2. F. Kiesler, Endless House (www.archdaily.com)

A contemporary approach of the surrealist concept of womb-house is offered by RV Prototype House project of the American architect Greg Lynn in which the interior is covered with an egg-like shell made of carbon fiber, exploring the stultification of the space necessary for dwelling and obtaining of a footprint as little as possible. The sensation of strangeness isemphasized by shaping a space in which the floor can become ceiling and inversely, the same asin the case of "Endless House" project, excepting that the movement freedom is stronger owing to a mechanism on the construction basis that can rotate it in any direction. Thus, the functionsand the furniture shape around the shell line, the curve lines simplifying the spatial flexibility. (Fig. 3)
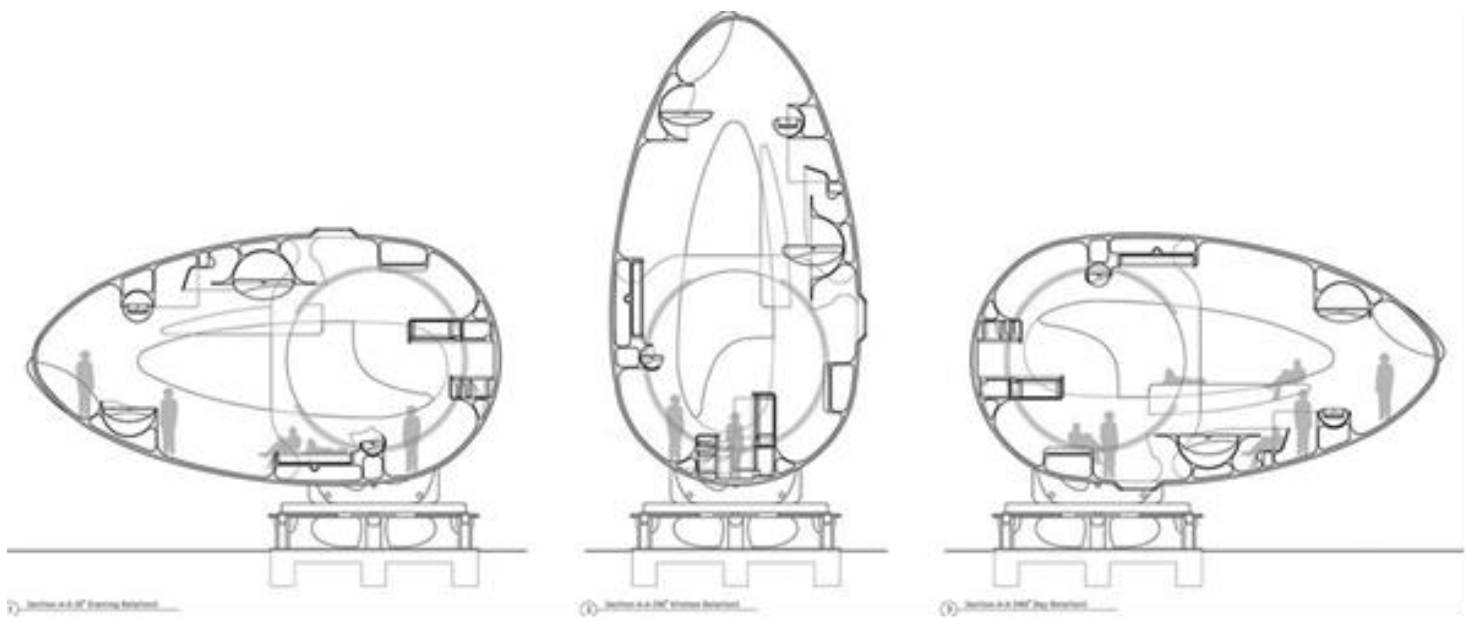

Fig. 3. G. Lynn, RV Prototype House (www.archdaily.com)

\section{Surrealism and Modernism}

Modern architecture triedto reach the rational by means of regulated white shapes, forming space with clear function. But, unusual dialog between rational and surrealism is shaped in strange atmosphere, sometimes sinister of the modern architecture brought to its apex in the buildings of Le Corbusier. Exterior-interior ambiguity, overwhelming sensation of absence and loneliness are only a few motifs offered in surrealist painting and found in the architect's buildings. Spatial ambiguity shapes in his buildings by integrating the nature as a defining 
component of the dwelling. Nature is considered as an extension of the interior room, determining the space-shelter of the housing and of the unknown to intertwine.

The natural component enclosed in the frame, found in architecture, is characteristic to the surreal painting and frequently used by the modernist architect in his projects. In case of the Pavillon de I'Esprit (Fig. 4) building, suppressing the double height wall of the terrace determines the nature to invade the space, at the same time enclosing it as in a painting. The delicate furniture-the tea table and the chairs- paint the overwhelming feeling of the human absence, but also the strange dimensions of the space. Alexander Gorlin in the "The Ghost in the Machine" work resembles the space in the "overscaled outdoor room" that seems to be in an unreal context with the space in the "Icar's Childhood" painting elaborated by the painter René Magritte in 1960: "In this Gargantuan room opening to the forest" (Gorlin 2005, 106) is a painting presenting the sky, supported by one with windows and in which the jockey galloping to the outside seams very little. Thus, resemblance emphasize through the frame enclosing the exterior and through the dimensional relation between object and space. (Fig. 5)

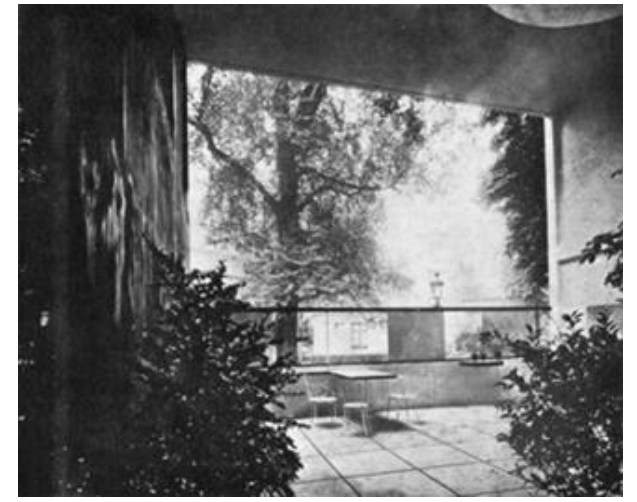

Fig. 4. Le Corbusier, Pavillon de l’ Esprit (T. Mical, Surrealism and Architecture)

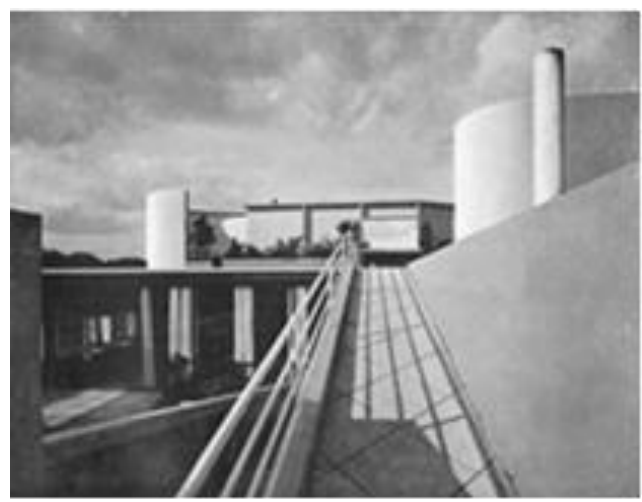

Fig. 6. Le Corbusier, Villa Savoye (T. Mical, Surrealism and Architecture)

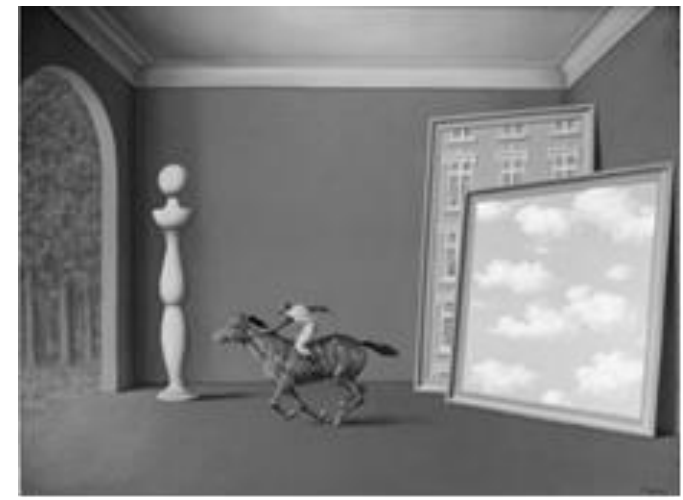

Fig. 5. René Magritte, Copilăria lui Icar (T. Mical, Surrealism and Architecture)

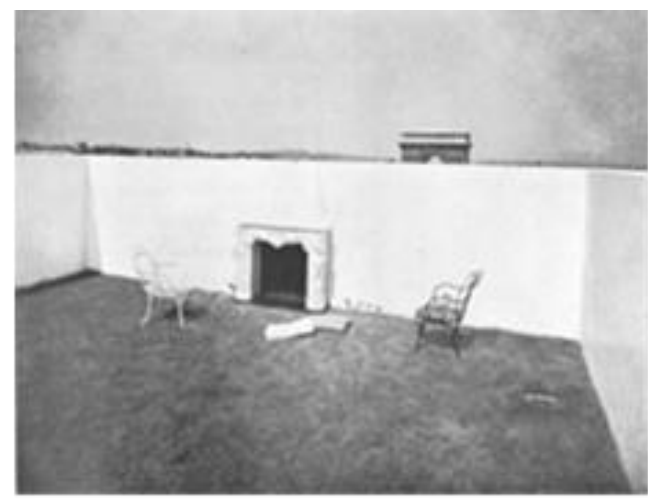

Fig. 7. Le Corbusier, Ap. Beistegui (T. Mical, Surrealism and Architecture)

The motif of the frame is present also at Villa Savoye, this time the painted component is the sky. The building is closed on the four sides, the interior being lit through windows in narrowbands, producing an ascending effect. The building seems an entire exterior room 
opening to the sky, an effect emphasized by the strange action of depicting a room on a roof displacing to the exterior suppressing the walls and the ceiling. (Fig. 6)

Beistegui flat is the most surreal work of Le Corbusier. The garden roof is treated as an exterior room from where the ceiling has been suppressed and where the walls act like a shield against the urban chaos, thus enclosing the sky as in a frame. The fireplace and the frail furniture on the grass floor cause an uncanny sensation. (Fig. 7)

The Surrealism described in the architecture of Le Corbusier reaches its apex in the architecture of Cordoba House, designed by Emilio Ambasz in 1975, in Seville (Fig. 8). The Andalusian landscape contributes to the completeness of the cube marked by both of the supple white walls, together producing a surreal image. Dwelling is underground, in a space delimited by curved shapes representing the womb-house concept. Thus, a feeling of safety and privacy occurs, being in contrast to the sensation of the exterior architecture. The inner court paints the surreal motif of the frame to the sky, whereas the both of the great walls contribute to the gradual passage from security to unknown, from the underground space to the overground one. This passage is marked by the stair ascending to the observation point, a stair symbolizing the knowledge road, sprinkled with fear. Thus, the architecture produces a dialog of exterior space, security and fear, succeeding in intertwining them. ( Fig. 9)

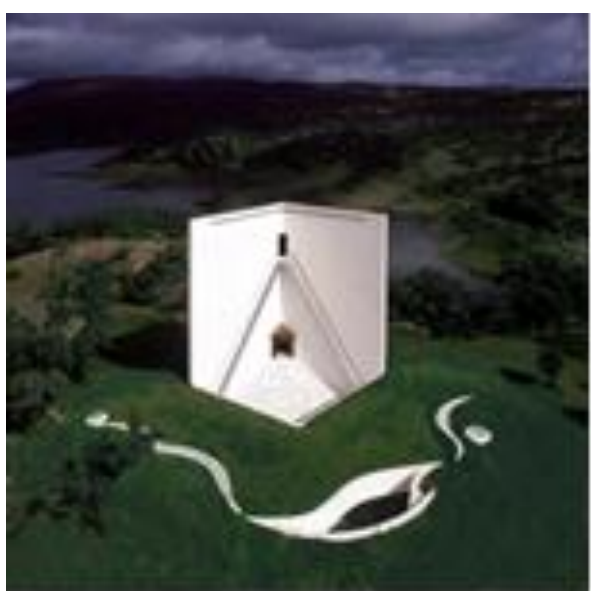

Fig. 8. E. Ambasz, Cordoba House (www.archdaily.com)

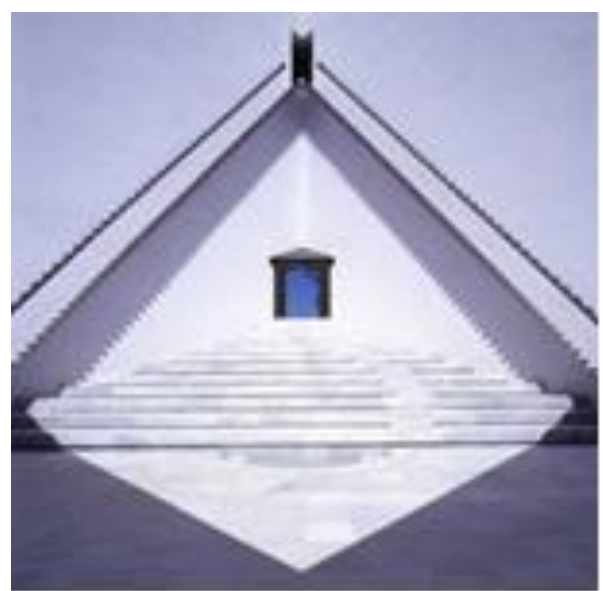

Fig. 9. E. Ambasz, Cordoba House (www.archdaily.com)

In the presented examples, the connection between architecture and surrealism enriches the spatial experience and produces sensations leading to a mental game of fear, mystery and comfort.

The surreal tinges do not limit only to the level of replacement program, the contemporary architects searching for the inspiration in this current for many other architecture programs.

\section{Human Body as a Source of Space Production}

The primary work object of surrealism was the body. Being in a continual metamorphosis process, it accumulates different mutations, from uncanny geometry, to machine and 
natural elements, becoming an ambiguous element, always being at the limit between material and immaterial. Through the mutilation of body, the surrealism produced a mirror of the human terror. In 1936, Salvador Dalí paints "Soft Construction of Boiled Beans (Premonition of the Civil War)" in which the torsion of the human body suggests the horrors of the war in which human destroys himself. The gruesom scene is emphasized by the boiled beans that remind of death, through the olfactory memory. (Fig. 10)

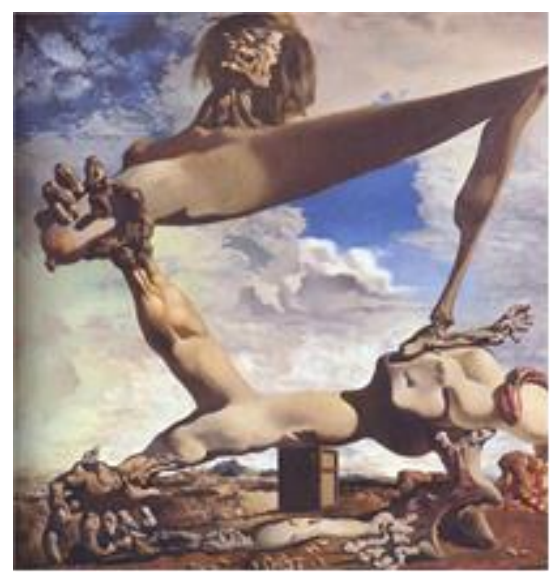

Fig. 10. S. Dali, Soft Construction with Boiled Beans (Premonition of the Civil War)

For Anthony Vidler, architects like Daniel Libeskind and Coop Himmelb(I)au establish in their works the concept of the human body inscription in architecture. But, this is considered as a metaphor shaped through extreme fragmentation - forming "a 'body' radically different from that at the center of the humanist tradition" Vidler 1996, 69). Thus, "This body no longer serves to center, to fix or to stabilize. Rather, its limits, interior or exterior, seem infinitely ambiguous and extensive; its forms, literal or metaphorical, are no longer confined to the recognizably human, but embrace all biological existence from the embryonic to the monstrous." (Vidler 1996, 70)

The Jewish Museum in Berlin designed by Daniel Libeskind in 1999, is based on the concept of human body fragmentation to the absence. "The body" is considered as a metaphor of pain and is felt at the level of voidspaces, of scratch-like windows and of tough architectural actions. (Fig. 11 and Fig. 12)

Other method of body exploitation as a tool of knowledge and production is approached by Coop Himmelb(I)au office. Within the "The Tower of Babel Revisited" work, the architects approach the body as an instrument of measuring the report between human and the components of the urban space: "Our eyes became towers, our foreheads bridges, our faces landscapes and our bodies the plan." (Coop Himmelb(I)au 1993, 29). This approach leads to body fragmentation to the limit in which it becomes unrecognizable, the component elements accumulating monstrous dimensions. In this way, the dimensional relation between human and city, the rapport of the human scale and urban environment scale are explored. This exploration is promoted through endeavor of modeling the human face in an architectural shape, through mutilation, Coop Himmelb(I)au showing it as "a natural façade of the emotions" (Coop Himmelb(I)au 1991, 21). Thus, construction and destruction can not be considered as antonyms, but as components collaborating to complete the work, at the concept level and 
the formal level. The architecture accumulates tumultuous shapes offering a restlessness sensation, a feeling that CoopHimmelb(I)au exploits as a fundamental element of the spatial experience.

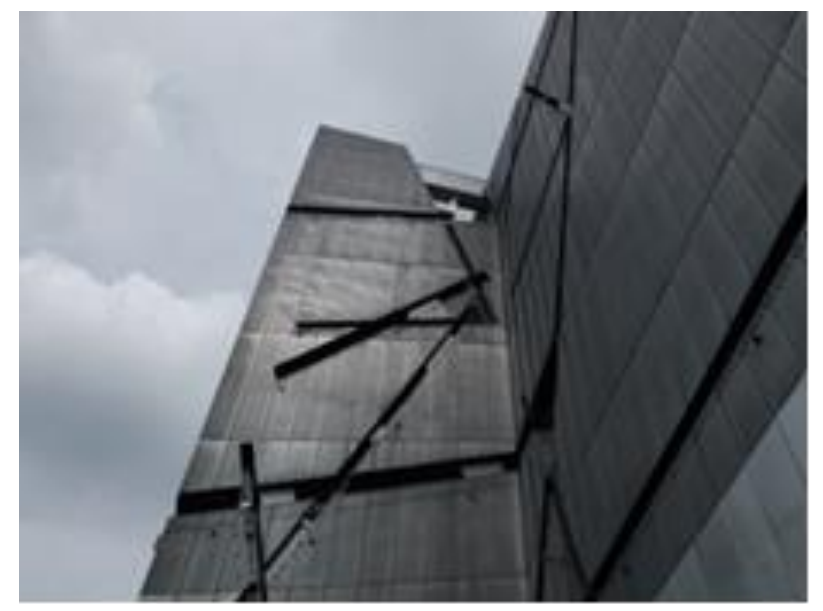

Fig. 11. D. Libeskind, Jewish Museum

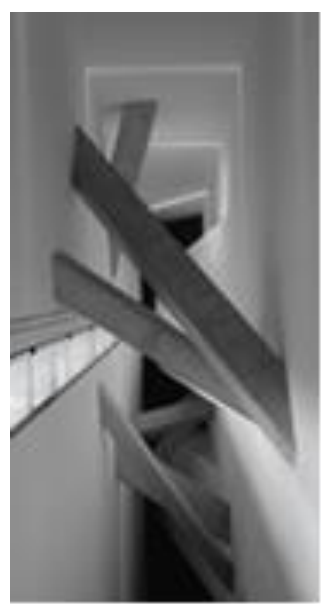

Fig. 12. D. Libeskind, Jewish Museum

The building that hosts the Contemporary Art Museum and the Exhibition of Planning (MoCAPE) in Shenzhen city, is characterized by interior-exterior ambiguity offered by the transparency with view to the city, the sensation resulted being of a covered exterior space. This example explores the visceral architecture by positioning a "heart" that produces a connection between the exposure spaces of both the museums, thus being united under the same shell. (Fig. 13 and Fig. 14)

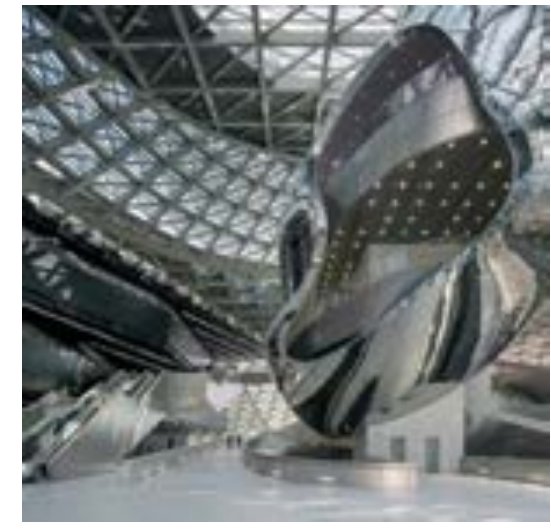

Fig. 13. C. Himmelb(I)au, MoCAPE (www.archdaily.com)

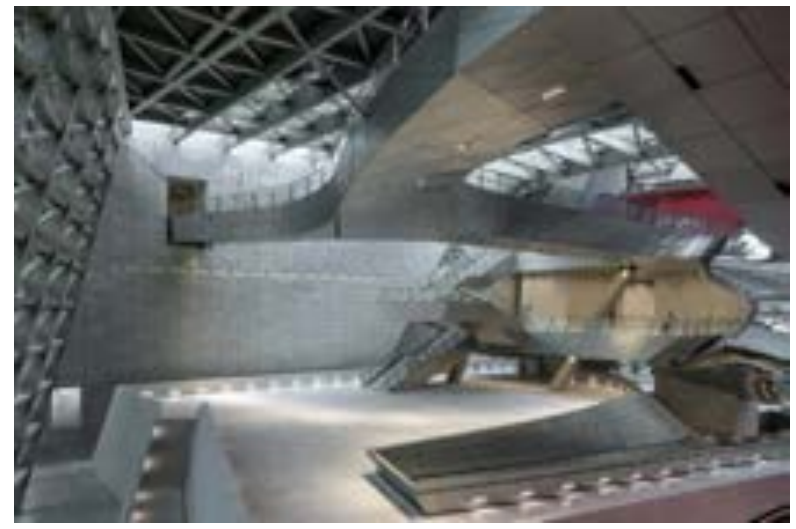

Fig. 14. C. Himmelb(I)au, MoCAPE (www.archdaily.com)

As a conclusion, the discovery of surreal components in the real space helps at better understanding the human mentality that tends to produce connexions between contradictory components. "Dwelling Machine" of Le Corbusier portrays ambiguous and strange relations of opposed components, as an apex of rational: sky and earth, interior-exterior, dwelling and absence. The surrealism also proved to be an inspiration source for architects, exploiting new means of space production and emotions submission. 
The embrace of the oneiric forms as part of human experience, extends it beyond the boundaries of rationality, which often leaves us indifferent to the hidden, intrinsic possibilities. The sensibility that each of us carries has the power to shape the environment into an infinity of personal realities. Architecture, through its essential tool-space, gives birth to inner feelings, creating a unique experience for each individual. The space of surrealism is embraced by sensuality because of it's ability to vibrate all senses. Thus, space is constantly moving and transforming itself over time, depending on the state of each individual inner world.

The essay aimed to introduce the reader into the spatial characteristics promoted by the Surrealist current, to awaken a certain curiosity towards exploring his or her own feelings in relation to the environment- to matter and the abstract.

\section{References}

Breton, André. (1969). „Manifestoes of Surrealism”, Richard Seaver și Helen R. Lane (trad.). Ann Arbor: The University of Michigan Press (ed)

Coop, Himmelb(I)au. (1991). „On the edge” în Architecture in Transition: Between Deconstruction and New Modernism, Peter Noever ( Munich:Prestel) (ed.)

Coop Himmelb(I)au. (1993). The Tower of Babel Revisited, ANY No. 0 (May/June)

Gorlin, Alexander. (2005). "The Ghost in the Machine” în Thomas Mical, Surrealism and Architecture, Routledge (ed.). Taylor \& Francis Group

Mical, Thomas. (2005). Surrealism and Architecture. Routledge (ed.), Taylor \& Francis Group

Troutman, Anne. (1997). „Inside fear: Secret places and Hidden Spaces in Dwelling”. Nan Ellin (ed.), Architecture and Fear, New York

Tzara, Tristan. (1933). „D`un certain automatisme du Gout”, Minotaure, 3-4, Decembrie

Vidler, Anthony. (1996). The Architectural Uncanny Essays in the Modern Unhomely. The MIT Press (ed.)

\section{Webography}

Archdaily http://www.archdaily.com

Dezeen http://www.dezeen.com/ 